\title{
Obilježja klime u Velebitskom podgorju
}

\author{
Damir Ugarković, Martin Nekić, Ivica Tikvić, Roman Rosavec, Krešimir Popić
}

\begin{abstract}
Nacrtak - Abstract
Velebitsko je podgorje klimatski specifičan dio Jadranskoga mora s najjačim udarima bure. Cilj je rada analizirati neke od glavnih klimatskih elemenata $i$ indeksa na području Velebitskoga podgorja. Analizirani su klimatski podaci s triju meteoroloških postaja: Senj na sjevernom dijelu, zatim Jablanac te Karlobag koji su smješteni na središnjem dijelu Velebitskoga podgorja. Prema Köppenu klima je u Velebitskom podgorju umjereno topla kišna klima. Na području Senja ljeta su gotovo bez pojave sušnoga razdoblja, dok je za preostale dvije meteorološke postaje karakteristično vruće ljeto s izrazitim sušnim razdobljem tijekom srpnja i početkom kolovoza. Prema vrijednostima Langova kišnoga faktora klima je u kanalu semihumidna. Od Senja prema jugu Velebitskoga podgorja povećavaju se vrijednosti srednje godišnje temperature zraka i iznosa potencijalne evapotranspiracije, a smanjuju se količine oborine i srednja brzina vjetra, međutim te promjene vrijednosti klimatskih elemenata nisu statistički značajne. Jedino se maksimalna brzina vjetra značajno smanjuje od Senja prema Karlobagu. Apsolutno kolebanje temperature zraka $u$ Velebitskom podgorju bilo je od $-10,4{ }^{\circ} \mathrm{C}$ do $39,7^{\circ} \mathrm{C}$, a maksimalna brzina vjetra iznosila je 32,7 bofora, dok je najučestaliji vjetar smjera istok - sjeveroistok odnosno sjeveroistok.
\end{abstract}

Ključne riječi: klima, klimatski elementi, klimatski indeksi, Velebitsko podgorje

\section{Uvod - Introduction}

S obzirom na to da je klima primaran stanišni čimbenik, motrenje klime i vremenskih prilika nekoga područja te njihova analiza prijeko su potrebni. O klimi ovisi čitav niz procesa ne samo u šumskim već $i$ ostalim ekosustavima. Ona utječe na svaki oblik ljudske gospodarske aktivnosti i na udobnost života ljudi. Klima utječe i na vegetaciju, uvjetujući raspored i građu Zemljina biljnoga pokrova, tako da je vegetacija u neposrednoj vezi s utjecajem klime (Vukelić i Rauš 1998). O vremenu i klimi hrvatskoga Jadrana pišu Penzar i dr. (2001), a također o klimi hrvatskoga Sredozemlja pišu Seletković i dr. (2011) s posebnim osvrtom na klimu mediteransko-litoralnoga vegetacijskoga pojasa za cijelo obalno i otočno područje istočnoga dijela Jadranskoga mora. U tom kontekstu autori su analizirali makroklimu hrvatskoga sredozemnoga područja. O mikroklimi šumskih ekosustava hrasta crnike i alepskoga bora pišu Ugarković i dr. (2017, 2019), međutim o mikroklimi šuma hrasta medunca gotovo da i nema istraživanja u Republici Hrvatskoj. $\mathrm{S}$ obzirom na podjelu mediteransko-litoralnoga vegetacijskoga pojasa Republike Hrvatske Velebitsko podgorje pripada u submediteransko područje u kojem je glavna ili edifikatorska vrsta šumskoga drveća hrast medunac, Quercus pubescens L. (Vukelić 2012). Velebitsko se podgorje nalazi u podnožju planine Velebit, a proteže se od Senja do rijeke Zrmanje. Uz Velebitsko se podgorje nalazi i Velebitski kanal, morski tjesnac u Jadranskom moru, čija duljina iznosi 121 km (Hrvatska enciklopedija). Velebitsko je podgorje hladniji dio hrvatskoga sredozemnoga područja, s jakim udarima bure i olujnim vjetrovima zimi. Na cijelom Jadranskom moru bura je najjača upravo u Velebitskom podgorju. Velebitsko podgorje na zapadu i jugu graniči s toplijim vegetacijskim područjem eumediteranom gdje je glavna vrsta šumskoga drveća hrast crnika, Quercus ilex L. (Vukelić 2012). S obzirom na specifičnosti mezoklime pojedinih područja, analizirat ćemo i opisati klimu Velebitskoga podgorja. Cilj je ovoga istraživanja podrobnije analizirati i opisati neke od glavnih klimatskih elemenata, kao što su temperatura zraka, količina oborine i brzina vjetra te neke klimatske indekse za Velebitsko podgorje.

\section{Materijal i metode rada - Material and methods}

Obilježja klime Velebitskoga podgorja predstavljena su temeljem analize klimatskih podataka s tri- 
ju meteoroloških postaja: Senj, Jablanac i Karlobag. Prikupljeni su podaci o vrijednostima temperature zraka $\left({ }^{\circ} \mathrm{C}\right)$, količine oborine $(\mathrm{mm})$ i brzine vjetra (bofor). Za meteorološke postaje Senj i Karlobag podaci su prikupljeni za razdoblje od 1993. do 2015. godine, dok su, nažalost, za meteorološku postaju Jablanac podaci bili dostupni samo za sedam godina motrenja za razdoblje od 1981. do 1987. godine. U radu je prikazana analiza i tih klimatskih podataka kraćega vremenskoga niza bez obzira na to što je za opis klime nekoga područja potrebno imati klimatske podatke za dulje razdoblje (Šegota i Filipčić 1996). Sve tri meteorološke postaje smještene su na obalnom dijelu Velebitskoga podgorja odnosno na istočnoj strani Velebitskoga kanala na duljini od $64 \mathrm{~km}$ od ukupne duljine Velebitskoga kanala koja iznosi $121 \mathrm{~km}$. Kao srednja (poprečna) temperatura $\mathrm{u}$ vegetacijskom razdoblju uzeta je temperatura od travnja do rujna. Toplinske oznake klime određene su prema vrijednostima srednje mjesečne temperature zraka ( ${ }^{\circ} \mathrm{C}$, Gračanin i Ilijanić 1977), a humidnost klime prema vrijednostima mjesečnih kišnih faktora (Gračanin 1950, Gračanin i Ilijanić 1977). Od klimatskih indeksa analizirani su Langov kišni faktor, indeks aridnosti, indeks kontinentalnosti, pluviotermički kvocijent te potencijalna evapotranspiracija. Langov kišni faktor izračunat je iz odnosa srednje godišnje količine oborine $(\mathrm{mm})$ i vrijednosti srednje godišnje temperature zraka $\left({ }^{\circ} \mathrm{C}\right)$ prema Langu (1915). Indeks aridnosti određen je prema Martonneu (1926), a indeks kontinentalnosti (k) prema metodi Conrada i Pollaka (1950). Pluviotermički kvocijent (Q) određen je prema Embergeru (1932). Potencijalna evapotranspiracija $(\mathrm{mm})$ izračunata je prema metodi Thornthwaitea (Šimunić 2013). Klimatski dijagrami, tj. grafički prikaz odnosa mjesečne temperature zraka i količine oborine, napravljeni su prema Walteru (1955). Klimatski podaci obrađeni su u programu KlimaSoft 2.0. Srednje i maksimalne vrijednosti brzine vjetra (bofor) za meteorološke postaje Senj i Karlobag uspoređene su Studentovim t-testom zavisnih uzoraka. Vrijednosti temperature zraka $\left({ }^{\circ} \mathrm{C}\right)$, količine oborine $(\mathrm{mm})$ i potencijalne evapotranspiracije $(\mathrm{mm})$ za sve meteorološke postaje $u$ Velebitskom podgorju analizirane su jednosmjernom analizom varijance (ANOVA). Statistička je obrada podataka napravljena u programu Statistica 7.1, a granica signifikantnosti iznosila je $p<0,05$.

\section{Rezultati istraživanja s raspravom - Results and discussion}

$\mathrm{U}$ tablici 1 prikazane su vrijednosti temperature zraka $\left({ }^{\circ} \mathrm{C}\right)$ za meteorološke postaje Senj, Jablanac i Karlobag. Srednja godišnja temperatura zraka bila je od $15,5^{\circ} \mathrm{C}$ na području Senja do $15,9^{\circ} \mathrm{C}$ na području meteorološke postaje Karlobag. Apsolutna maksimalna temperatura zraka bila je od $37,0{ }^{\circ} \mathrm{C} \mathrm{u}$ Jablancu do $39,7^{\circ} \mathrm{C}$ u Senju. Apsolutna minimalna temperatura zraka kretala se od $-9,5^{\circ} \mathrm{C}$ (Jablanac i Karlobag) do $-10,4{ }^{\circ} \mathrm{C}$ na području Senja. Najveće apsolutno kolebanje temperature zraka zabilježeno je na meteorološkoj postaji Senj u iznosu od $50,1^{\circ} \mathrm{C}$. Prema rezultatima ANOVA nisu utvrđene statistički značajne razlike $\mathrm{u}$ vrijednostima temperature zraka između meteoroloških postaja u Velebitskom podgorju $(\mathrm{F}=0,01, \mathrm{p}=0,989)$.

Tablica 1. Vrijednosti temperature zraka $\left({ }^{\circ} \mathrm{C}\right)$ za meteorološke postaje u Velebitskom podgorju

Table 1 Air temperature values $\left({ }^{\circ} \mathrm{C}\right)$ for meteorological stations in Velebit Podgorje

\begin{tabular}{|c|c|c|c|c|c|c|}
\hline \multirow{2}{*}{$\begin{array}{c}\text { Meteorološke postaje } \\
\text { Meteorological stations }\end{array}$} & \multicolumn{5}{|c|}{ Temperatura zraka, ${ }^{\circ} \mathrm{C}$ - Air temperature, ${ }^{\circ} \mathrm{C}$} \\
\cline { 2 - 7 } & SG & SV & AMAX & AMIN & SK & AK \\
\hline Senj & 15,5 & 21,2 & 39,7 & $-10,4$ & 18,8 & 50,1 \\
\hline Jablanac & 15,6 & 21,0 & 37,0 & $-9,5$ & 18,6 & 46,5 \\
\hline Karlobag & 15,9 & 21,6 & 38,7 & $-9,5$ & 19,2 & 48,2 \\
\hline
\end{tabular}

SG - srednja godišnja - average annual; SV - srednja vegetacijska - average vegetation; AMAX - apsolutna maksimalna - absolute maximum; AMIN apsolutna minimalna - absolute minimum; SK - srednje kolebanje - medium fluctuation; AK - apsolutno kolebanje - absolute fluctuation

Tablica 2. Srednja mjesečna temperatura zraka $\left({ }^{\circ} \mathrm{C}\right)$ i toplinske oznake klime za meteorološke postaje u Velebitskom podgorju Table 2 Mean monthly air temperatures $\left({ }^{\circ} \mathrm{C}\right)$ and heat codes for meteorological stations in Velebit Podgorje

\begin{tabular}{|c|c|c|c|c|c|c|c|c|c|c|c|c|}
\hline \multirow{2}{*}{$\begin{array}{l}\text { Meteorološke postaje } \\
\text { Meteorological stations }\end{array}$} & \multicolumn{12}{|c|}{ Mjeseci-Months } \\
\hline & I. & II. & III. & IV. & V. & VI. & VII. & VIII. & IX. & $\mathrm{X}$ & XI. & XII. \\
\hline Senj & $\begin{array}{l}6,8 \\
\text { uhl }\end{array}$ & $\begin{array}{l}6,9 \\
\text { uhl }\end{array}$ & $\begin{array}{c}10,1 \\
\text { ut }\end{array}$ & $\begin{array}{c}14,0 \\
t\end{array}$ & $\begin{array}{c}18,9 \\
t\end{array}$ & $\begin{array}{c}23,0 \\
v\end{array}$ & $\begin{array}{c}25,6 \\
v\end{array}$ & $\begin{array}{c}25,3 \\
v\end{array}$ & $\begin{array}{c}20,1 \\
v\end{array}$ & $\begin{array}{c}16,0 \\
t\end{array}$ & $\begin{array}{c}11,6 \\
\text { ut }\end{array}$ & $\begin{array}{l}7,9 \\
\text { uhl }\end{array}$ \\
\hline Jablanac & $\begin{array}{l}6,9 \\
\text { uhl } \\
\end{array}$ & $\begin{array}{l}6,2 \\
\text { uhl } \\
\end{array}$ & $\begin{array}{l}9,5 \\
\text { ut }\end{array}$ & $\begin{array}{c}13,5 \\
t\end{array}$ & $\begin{array}{c}17,7 \\
t\end{array}$ & $\begin{array}{c}24,4 \\
V\end{array}$ & $\begin{array}{c}24,8 \\
V\end{array}$ & $\begin{array}{c}24,6 \\
\mathrm{~V}\end{array}$ & $\begin{array}{c}21,2 \\
v\end{array}$ & $\begin{array}{c}16,9 \\
t\end{array}$ & $\begin{array}{c}11,8 \\
\mathrm{ut}\end{array}$ & $\begin{array}{l}9,3 \\
\text { ut }\end{array}$ \\
\hline Karlobag & $\begin{array}{l}6,9 \\
\text { uhl }\end{array}$ & $\begin{array}{l}7,3 \\
\text { uhl }\end{array}$ & $\begin{array}{c}10,3 \\
\text { ut }\end{array}$ & $\begin{array}{c}14,0 \\
t\end{array}$ & $\begin{array}{c}19,3 \\
t\end{array}$ & $\begin{array}{c}23,6 \\
v\end{array}$ & $\begin{array}{c}26,1 \\
v\end{array}$ & $\begin{array}{c}25,7 \\
\vee\end{array}$ & $\begin{array}{c}20,8 \\
v\end{array}$ & $\begin{array}{c}16,6 \\
t\end{array}$ & $\begin{array}{c}11,8 \\
\text { ut }\end{array}$ & $\begin{array}{l}8,5 \\
\text { ut }\end{array}$ \\
\hline
\end{tabular}

v - vruća - hot $\left(>20^{\circ} \mathrm{C}\right) ; \mathrm{t}$ - topla - warm $\left(12-20^{\circ} \mathrm{C}\right)$; ut - umjereno topla - moderatly warm $\left(8-12^{\circ} \mathrm{C}\right)$; uhl - umjereno hladna - moderately cold $\left(4-8{ }^{\circ} \mathrm{C}\right)$; $\mathrm{h}$ - hladna - cold $\left(0,5-4{ }^{\circ} \mathrm{C}\right) ; \mathrm{n}$ - nivalna - nival $\left(<0,5^{\circ} \mathrm{C}\right)$ 
U tablici 2 prikazana je srednja mjesečna temperatura zraka za meteorološke postaje u Velebitskom podgorju te toplinska oznaka klime. S obzirom na toplinsku oznaku klime mjeseci su bili umjereno hladni, umjereno topli, topli i vrući. Najveći je bio broj vrućih mjeseci, i to po četiri vruća mjeseca na svakoj meteorološkoj postaji. Na meteorološkoj postaji Senj najmanji je broj umjereno toplih mjeseci, dok je na meteorološkim postajama Jablanac i Karlobag najmanji broj umjereno hladnih mjeseci.

Srednja godišnja količina oborine iznosila je od 1212,6 mm na području Karlobaga do 1348,5 mm na području Jablanca. Postotak količine oborine od travnja do rujna iznosio je $40 \%$ za meteorološku postaju Karlobag, 41 \% za meteorološku postaju Jablanac i 44 $\%$ za meteorološku postaju Senj (tablica 3). Nisu postojale statistički značajne razlike $\mathrm{u}$ količini oborine za te meteorološke postaje $(F=0,25, p=0,776)$.

Tablica 3. Količina oborine $(\mathrm{mm})$ za meteorološke postaje u Velebitskom podgorju

Table 3 Precipitation $(\mathrm{mm})$ for meteorological stations in the Velebit Podgorje

\begin{tabular}{|c|c|c|c|}
\hline \multirow{2}{*}{$\begin{array}{c}\text { Meteorološke } \\
\text { postaje }\end{array}$} & \multicolumn{3}{|c|}{ Količina oborine, $\mathrm{mm}$ - Precipitation amount, $\mathrm{mm}$} \\
\cline { 2 - 4 } $\begin{array}{c}\text { Meteorological } \\
\text { stations }\end{array}$ & $\begin{array}{c}\text { Srednja godišnja } \\
\text { Average annual }\end{array}$ & $\begin{array}{c}\text { Srednja } \\
\text { vegetacijska } \\
\text { Average } \\
\text { vegetation }\end{array}$ & $\begin{array}{c}\text { \% u veg. } \\
\text { razdoblju } \\
\% \text { in veg. period }\end{array}$ \\
\hline Senj & 1278,1 & 556,7 & 44 \\
\hline Jablanac & 1348,5 & 556,6 & 41 \\
\hline Karlobag & 1212,6 & 481,5 & 40 \\
\hline
\end{tabular}

U tablici 4 prikazane su srednje mjesečne količine oborine (mm), Gračaninovi mjesečni kišni faktori i humidnost klime.
Na području Senja zabilježena su po 4 perhumidna i 4 humidna mjeseca, te po 2 semiaridna i 2 aridna mjeseca. Meteorološka postaja Jablanac imala je 3 perhumidna mjeseca, 5 humidnih mjeseci, 1 semihumidni mjesec 1 semiaridni mjesec i 2 aridna mjeseca. Na području Karlobaga zabilježena su po 3 perhumidna mjeseca, 5 humidnih mjeseci, samo 1 semiaridni mjesec i 3 aridna mjeseca (tablica 4).

Srednja brzina vjetra na meteorološkoj postaji Senj kretala se od 1,5 bofora do 10,5 bofora, a maksimalna je bila $u$ rasponu od 9,4 bofora do 30,4 bofora. Na meteorološkoj postaji Karlobag srednja je brzina vjetra bila $u$ rasponu od 1,5 bofora do 6,4 bofora. Na istoj meteorološkoj postaji maksimalna brzina vjetra bila je u rasponu od 6,7 bofora do 22,6 bofora (tablica 5).

Najučestaliji je smjer vjetra na sjevernom dijelu Velebitskoga podgorja, na meteorološkoj postaji Senj, istok - sjeveroistok s čestinom od 34,85\%. Na meteorološkoj postaji Karlobag smjer je najučestalijega vjetra sjeveroistok s čestinom od 25,42\%. Postotak broja dana s tišinom, odnosno postotak broja dana bez vjetra na meteorološkoj postaji Senj iznosio je 7,46 \%, a na meteorološkoj postaji Karlobag 0,69\%. Nisu utvrđene statistički značajne razlike $(\mathrm{t}=0,01, \mathrm{p}=0,991)$ u srednjoj brzini vjetra između meteorološke postaje Senj (2,98 bofora) i Karlobag (2,97 bofora), dok su statistički značajne razlike $(t=5,14, p=0,000)$ utvrđene u maksimalnoj brzini vjetra između meteoroloških postaja Senj i Karlobag. Na pojedinim mjestima zbog posebnih okolnosti povećava se brzina vjetra iz određenoga smjera, a na Jadranskom moru to se događa u obalnom području kad hladan zrak s kopna struji prema moru (Penzar i dr. 2001). Prema istim autorima na našoj je jadranskoj obali najveća srednja brzina vjetra u siječnju ili veljači, jer su to mjeseci s najviše

Tablica 4. Srednje mjesečne količine oborine $(\mathrm{mm})$, mjesečni kišni faktori i humidnost klime za meteorološke postaje u Velebitskom podgorju

Table 4 Mean monthly precipitation $(\mathrm{mm})$, monthly rain factors and climate humidity for meteorological stations in Velebit Podgorje

\begin{tabular}{|c|c|c|c|c|c|c|c|c|c|c|c|c|c|}
\hline \multirow{2}{*}{\multicolumn{2}{|c|}{$\begin{array}{l}\text { Postaja/element/indeks } \\
\text { Station/element/index }\end{array}$}} & \multicolumn{12}{|c|}{ Mjeseci - Months } \\
\hline & & I. & II. & III. & IV. & V. & VI. & VII. & VIII. & IX. & $\mathrm{X}$ & $\mathrm{XI}$. & XII. \\
\hline \multirow{3}{*}{ Senj } & $P$ & 99,2 & 92,7 & 77,7 & 95,5 & 86,3 & 72,9 & 46,9 & 85,8 & 169,3 & 144,9 & 171,4 & 135,5 \\
\hline & $\mathrm{KF}$ & 14,6 & 13,4 & 7,7 & 6,8 & 4,6 & 3,2 & 1,8 & 3,4 & 8,4 & 9,1 & 14,8 & 17,2 \\
\hline & $\mathrm{H}$ & $\mathrm{ph}$ & $\mathrm{ph}$ & $\mathrm{h}$ & $\mathrm{h}$ & sa & $a$ & $a$ & sa & $\mathrm{h}$ & $\mathrm{h}$ & $\mathrm{ph}$ & $\mathrm{ph}$ \\
\hline \multirow{3}{*}{ Jablanac } & $P$ & 128,5 & 144,9 & 117,6 & 98,7 & 119,3 & 97,6 & 35,8 & 77,5 & 127,7 & 152,3 & 94,0 & 154,6 \\
\hline & KF & 18,6 & 23,4 & 12,4 & 7,3 & 6,7 & 4,0 & 1,4 & 3,2 & 6,0 & 9,0 & 8,0 & 16,6 \\
\hline & $\mathrm{H}$ & $\mathrm{ph}$ & $\mathrm{ph}$ & $\mathrm{h}$ & $\mathrm{h}$ & $\mathrm{h}$ & sa & $\mathrm{a}$ & $\mathrm{a}$ & sh & $\mathrm{h}$ & $\mathrm{h}$ & $\mathrm{ph}$ \\
\hline \multirow{3}{*}{ Karlobag } & $\mathrm{P}$ & 109,1 & 94,9 & 86,3 & 95,3 & 77,4 & 57,4 & 33,3 & 55,8 & 162,3 & 131,4 & 157,5 & 151,9 \\
\hline & $\mathrm{KF}$ & 15,8 & 13,0 & 8,4 & 6,8 & 4,0 & 2,4 & 1,3 & 2,2 & 7,8 & 7,9 & 13,3 & 17,9 \\
\hline & $\mathrm{H}$ & $\mathrm{ph}$ & $\mathrm{h}$ & $\mathrm{h}$ & $\mathrm{h}$ & sa & $a$ & $a$ & $a$ & $\mathrm{~h}$ & $\mathrm{~h}$ & ph & $\mathrm{ph}$ \\
\hline
\end{tabular}

$\mathrm{P}$ - oborina, $\mathrm{mm}$ - precipitation, $\mathrm{mm}$; KF - kišni faktor - rain factor; $\mathrm{H}$ - humidnost klime - climate humidity; ph - perhumdina - perhumid (> 13,3); $\mathrm{h}$ - humidna humid (6,7 - 13,3); sh - semihumidna - semihumide $(5,1$ - 6,6); sa - semiardna - semiarid $(3,4-5,0)$; a - aridna - arid $(1,7-3,3)$; pa - peraridna - perarid $(<1,6)$ 
Tablica 5. Srednja i maksimalna brzina vjetra (bofor) za meteorološke postaje Senj i Karlobag Table 5 Average and maximum wind speeds (Beaufort) for meteorological stations Senj and Karlobag

\begin{tabular}{|c|c|c|c|c|}
\hline \multirow{2}{*}{$\begin{array}{c}\text { Smjer vjetra } \\
\text { Wind direction }\end{array}$} & \multicolumn{3}{|c|}{ Meteorološke postaje - Meteorological stations } \\
\cline { 2 - 5 } & Srednja - Average & Maksimalna - Maximum & Srednja - Average & Maksimalna - Maximum \\
\cline { 2 - 5 } & 1,9 & 15,5 & 1,5 & 9,4 \\
\hline NNE & 2,7 & 18,5 & 6,4 & 15,5 \\
\hline NE & 3,7 & 30,4 & 6,3 & 22,6 \\
\hline ENE & 10,5 & 32,7 & 3,7 & 15,5 \\
\hline E & 4,8 & 22,6 & 1,6 & 18,5 \\
\hline ESE & 2,6 & 18,5 & 2,6 & 12,3 \\
\hline SE & 2,0 & 18,5 & 3,1 & 15,5 \\
\hline SSE & 3,4 & 18,5 & 2,7 & 12,3 \\
\hline S & 2,1 & 15,5 & 1,7 & 6,7 \\
\hline SSW & 3,0 & 12,3 & 2,2 & 6,7 \\
\hline SW & 2,3 & 9,4 & 2,4 & 6,7 \\
\hline WSW & 1,9 & 12,3 & 2,7 & 6,7 \\
\hline W & 1,5 & 9,4 & 2,4 & 6,7 \\
\hline WNW & 1,5 & 12,3 & 2,7 & 9,4 \\
\hline NW & 1,7 & 18,5 & 2,9 & 9,4 \\
\hline NNW & 2,1 & 9,4 & 2,7 & 12,3 \\
\hline
\end{tabular}

bure. Bura može biti i ljeti kada se kratkotrajni prodor hladnoga zraka s Atlantika, krećući se prema istoku, prelije do naših Dinarida. Zračna struja koja puše s kopna prema moru, prelazi planine okomito odnosno najkraćim putem, a time je uz obalu povećana čestina sjeveroistočnoga vjetra (Penzar i dr. 2001). Bura je $\mathrm{u}$ Velebitskom podgorju izrazito jaka jer zračna struja na prijelazu s kopna prema Jadranskomu moru ima karakterističan smjer, okomito na Velebit niz koji se ruši. Prema Penzaru i dr. (2001) od svih gradova na Jadranskoj obali najviše bure ima Senj, jer je smješten na samoj granici između mora i Velebita koji je ondje uži nego drugdje duž obale.

Prema Gausenu (1954) trajanje sušnoga razdoblja na mjesečnoj razini može se izračunati iz odnosa $\mathrm{P}<$ 2T, dakle mjesec u kojem je iznos oborine $\mathrm{P} u(\mathrm{~mm})$ manji od dva iznosa srednje mjesečne temperature toga mjeseca T $\left({ }^{\circ} \mathrm{C}\right)$ sušan je mjesec. Prema tom od-
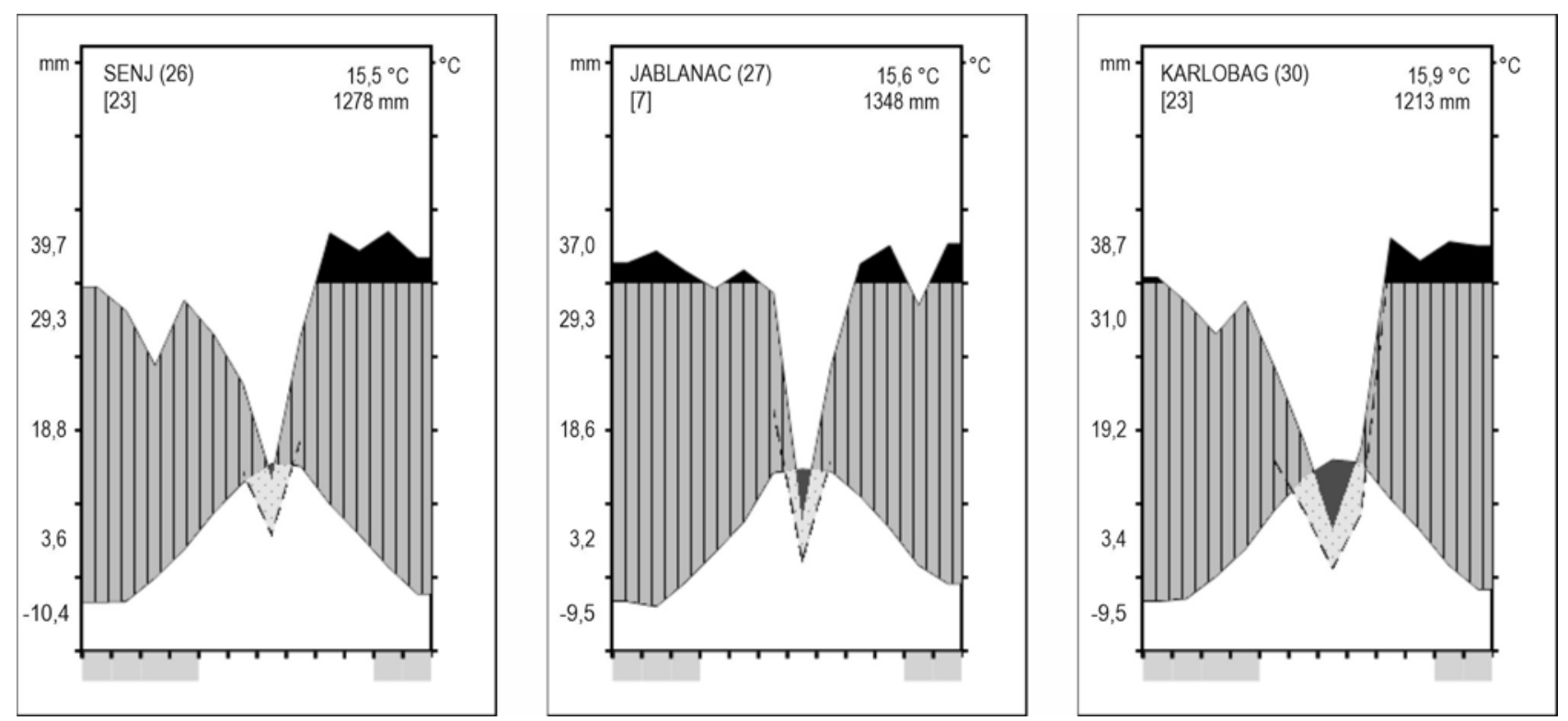

Slika 1. Klimatski dijagrami za meteorološke postaje Senj, Jablanac i Karlobag

Fig. 1 Climate diagrams for meteorological stations Senj, Jablanac and Karlobag 
nosu na svim trima meteorološkim postajama u Velebitskom podgorju sušni je mjesec srpanj.

Na slici 1 prikazani su klimatski dijagrami za meteorološke postaje Senj, Jablanac i Karlobag. Sve tri meteorološke postaje imaju maritimni oborinski režim, odnosno minimalne su količine oborine $u$ ljetnim mjesecima. Najsuši je mjesec srpanj, kada je ujedno i najmanja količina oborine. Srpanj je i najtopliji mjesec sa srednjom temperaturom zraka većom od $22{ }^{\circ} \mathrm{C}$. Najveće količine oborine na području Senja, iznad $100 \mathrm{~mm}$ mjesečno, padaju od rujna do prosinca. Prema Walterovu klimatskom dijagramu na području Senja gotovo da i ne postoji sušno razdoblje. Mjeseci s količinom oborine iznad $100 \mathrm{~m}$ na području Jablanca su siječanj, veljača, ožujak, svibanj, studeni i prosinac, a sušno je razdoblje u srpnju. Suša na području Karlobaga izraženija je i počinje se javljati već koncem lipnja pa do prve polovice kolovoza. Mjeseci s količinom oborine iznad $100 \mathrm{~m}$ su siječanj te od rujna do prosinca.

Na meteorološkoj postaji Senj apsolutna minimalna temperatura zraka ispod $0{ }^{\circ} \mathrm{C}$ kreće se od siječnja do travnja, te $\mathrm{u}$ studenom i prosincu. Apsolutna minimalna temperatura zraka na postaji Jablanac javlja se od siječnja do ožujka te u studenom i prosincu. Mogućnost pojave mraza u Karlobagu, odnosno mjeseci $\mathrm{s}$ apsolutnom temperaturom zraka ispod $0{ }^{\circ} \mathrm{C}$, javlja se od siječnja do travnja te u studenom i prosincu.

Tablica 6. Klimatski indeksi za meteorološke postaje u Velebitskom podgorju

Table 6 Climate indices for meteorological stations in Velebit Podgorje

\begin{tabular}{|c|c|c|c|c|}
\hline \multirow{2}{*}{$\begin{array}{c}\text { Meteorološke } \\
\text { postaje } \\
\begin{array}{c}\text { Meteorological } \\
\text { stations }\end{array}\end{array}$} & \multicolumn{4}{|c|}{ Klimatski indeksi - Climate indices } \\
\cline { 2 - 5 } Senj & $\begin{array}{c}82,37 \\
\text { Semihumidna } \\
\text { Semihumide }\end{array}$ & $\begin{array}{c}50,1 \\
\text { Humidna } \\
\text { Humid }\end{array}$ & $\begin{array}{c}39,34 \\
\text { Kontinentalna } \\
\text { Continental }\end{array}$ & $\begin{array}{c}151,16 \\
\text { Perhumidna } \\
\text { Perhumid }\end{array}$ \\
\hline Jablanac & $\begin{array}{c}86,63 \\
\text { Semihumidna } \\
\text { Semihumide }\end{array}$ & $\begin{array}{c}52,7 \\
\text { Humidna } \\
\text { Humid }\end{array}$ & $\begin{array}{c}40,57 \\
\text { Kontinentalna } \\
\text { Continental }\end{array}$ & $\begin{array}{c}157,88 \\
\text { Perhumidna } \\
\text { Perhumid }\end{array}$ \\
\hline Karlobag & $\begin{array}{c}76,22 \\
\text { Semihumidna } \\
\text { Semihumide }\end{array}$ & $\begin{array}{c}46,8 \\
\text { Humidna } \\
\text { Humid }\end{array}$ & $\begin{array}{c}43,61 \\
\text { Kontinentalna } \\
\text { Continental }\end{array}$ & $\begin{array}{c}127,72 \\
\text { Humidna } \\
\text { Humid }\end{array}$ \\
\hline
\end{tabular}

LKf - Langov kišni faktor - Lang's rain factor; IA - indeks aridnosti - aridity index; $\mathrm{k}$ - indeks (stupanj) kontinentalnosti - continentality index; Q pluviotermički kvocijent - pluviothermal quotient

Klima je u Velebitskom podgorju prema Langovu kišnom faktoru semihumidna, a prema indeksu aridnosti je humidna. S obzirom na vrijednosti pluviotermičkoga kvocijenta područje je Senja i Jablanca perhumidno, a područje je Karlobaga humidno (tablica 6).

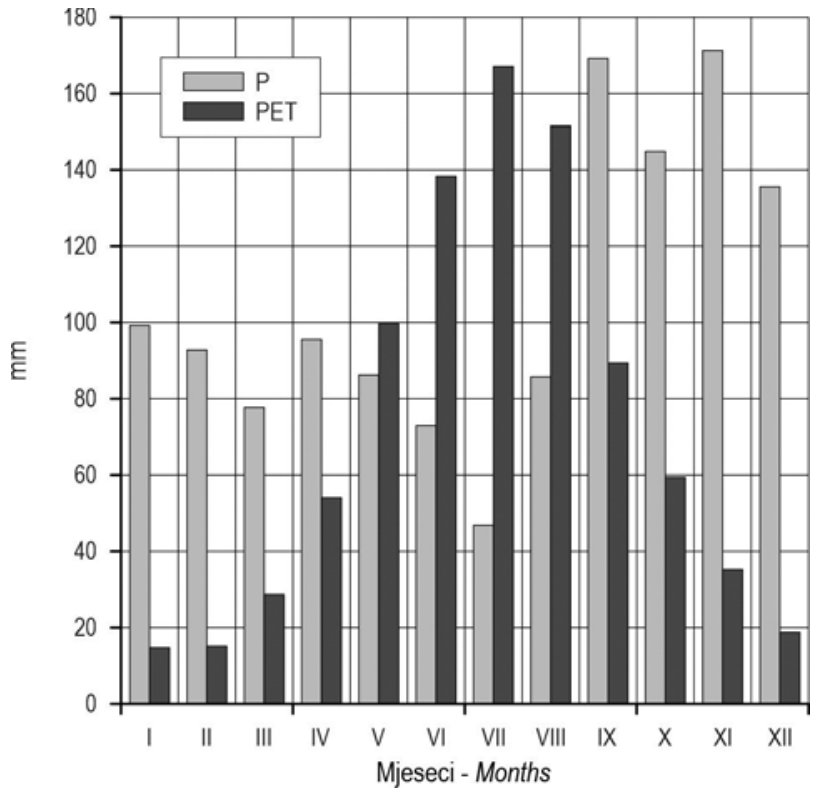

Slika 2. Odnos oborine $P(\mathrm{~mm})$ i potencijalne evapotranspiracije PET (mm) za meteorološku postaju Senj

Fig. 2 Ratio of precipitation $P(\mathrm{~mm})$ and potential evapotranspiration PET $(\mathrm{mm})$ for meteorological station Senj

Na slici 2 prikazan je odnos količine oborine $(\mathrm{mm})$ i potencijalne evapotranspiracije $(\mathrm{mm})$ za meteorološku postaju Senj. Najmanji deficit vode u ekosustavu bio je u svibnju $(-13,4 \mathrm{~mm})$, a najveći u srpnju $(-120,3 \mathrm{~mm})$.

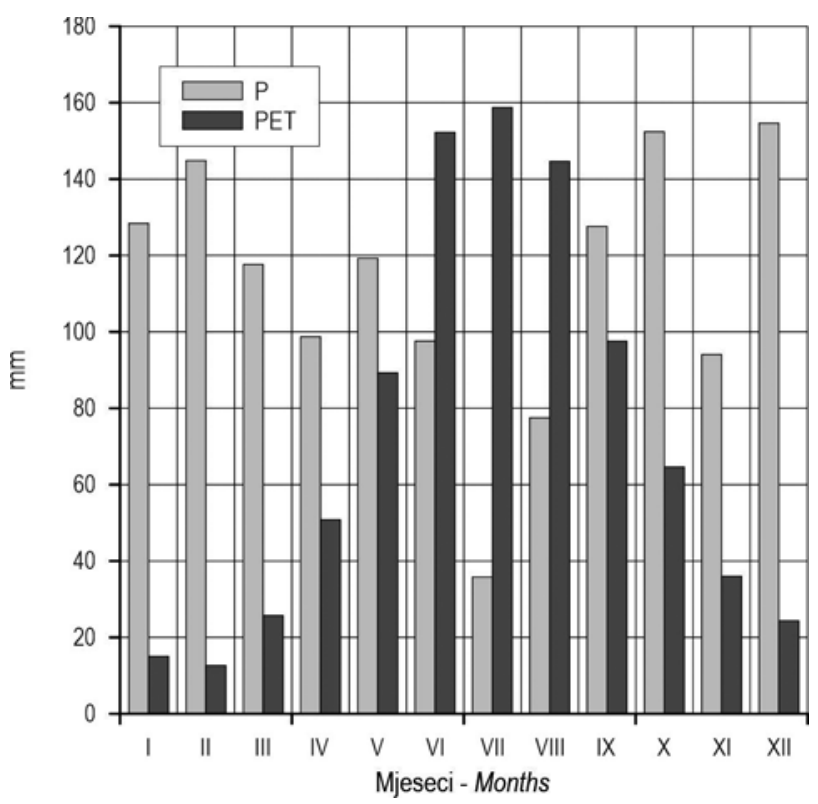

Slika 3. Odnos oborine $P(\mathrm{~mm})$ i potencijalne evapotranspiracije PET (mm) za meteorološku postaju Jablanac

Fig. 3 Ratio of precipitation $P(\mathrm{~mm})$ and potential evapotranspiration PET (mm) for meteorological station Jablanac 
Na meteorološkoj postaji Jablanac (slika 3) najmanji deficit vode $\mathrm{u}$ ekosustavu bio je $\mathrm{u}$ lipnju $\mathrm{u}$ iznosu od $-54,6 \mathrm{~mm}$, a najveći u srpnju u iznosu od $-122,9 \mathrm{~mm}$.

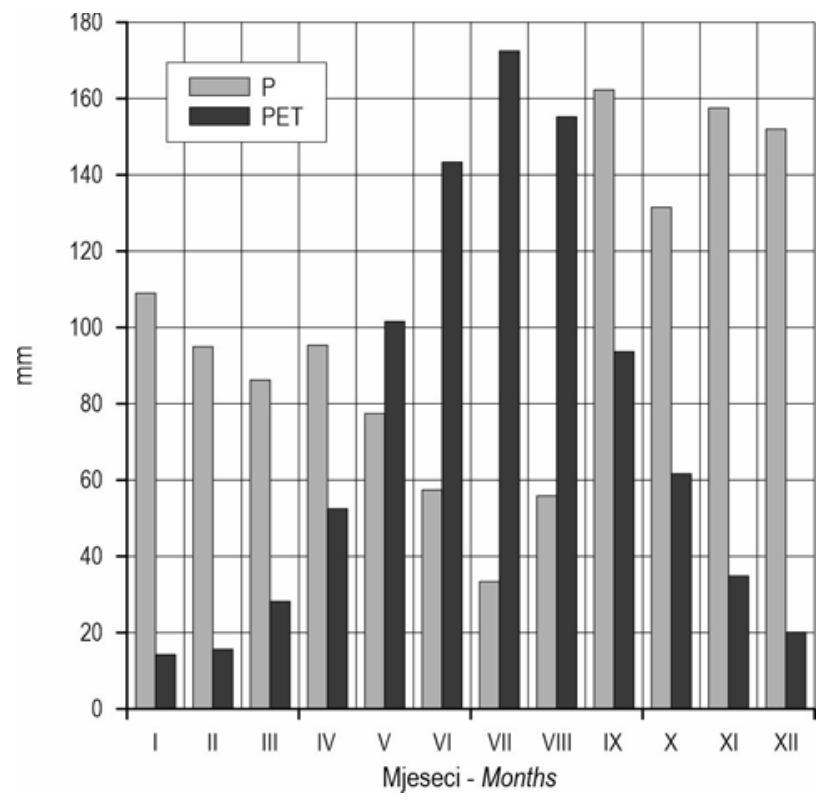

Slika 4. Odnos oborine $P(\mathrm{~mm})$ i potencijalne evapotranspiracije PET (mm) za meteorološku postaju Karlobag

Fig. 4 Ratio of precipitation $P(\mathrm{~mm})$ and potential evapotranspiration PET (mm) for meteorological station Karlobag

Na meteorološkoj postaji Karlobag (slika 4) najmanji deficit vode $\mathrm{u}$ ekosustavu bio je $\mathrm{u}$ svibnju $(-24,2 \mathrm{~mm})$, a najveći u srpnju $(-139,1 \mathrm{~mm})$.

Nisu utvrđene statistički značajne razlike u količini potencijalne evapotranspiracije $(\mathrm{F}=0,00, \mathrm{p}=$ $0,995)$ za meteorološke postaje Senj, Jablanac i Karlobag.

Jug Velebitskoga podgorja kontaktna je zona prema eumediteranu i kopnenomu (obalnomu) arealu hrasta crnike (Quercus ilex L.) u Republici Hrvatskoj pa se stoga prema jugu Velebitskoga podgorja povećavaju, iako ne statistički značajno, srednje vrijednosti temperature zraka, iznosa potencijalne evapotranspiracije, a smanjuju se količine oborine, što sve skupa utječe i na dulje trajanje suše na jugu Velebitskoga podgorja u odnosu na sjevernu granicu podgorja. Također prema jugu Velebitskoga podgorja i zoni eumediterana smanjuju se srednja brzina vjetra, dok je smanjenje maksimalne brzine vjetra statistički značajno te je manji broj dana tišine, odnosno manji broj dana bez vjetra.

\section{Zaključci - Conclusions}

Prema Köppenu klima je u Velebitskom podgorju umjereno topla kišna klima (Senj, Cfwax) te umjereno topla kišna klima s vrućim ljetom na području Jablanca i Karlobaga (tip Csa). Srednja se godišnja temperatura zraka kretala od $15,5^{\circ} \mathrm{C}$ do $15,9^{\circ} \mathrm{C}$, a količina je oborine bile $\mathrm{u}$ rasponu od 1212,6 $\mathrm{mm}$ do $1348,5 \mathrm{~mm}$. Oborinski je režim u Velebitskom podgorju maritiman s najmanjom količinom oborine u ljetnim mjesecima, konkretno u srpnju. Prema Walterovim klimatskim dijagramima na području Senja gotovo da i nema sušnoga razdoblja, dok se idući prema jugu Velebitskoga podgorja povećava vremensko trajanje suše. Na području Jablanca suša se javlja u srpnju, dok na području Karlobaga suša počinje koncem lipnja i traje do početka kolovoza. Prema odnosu količine oborine i potencijalne evapotranspiracije razdoblje s manjkom količine vode traje od svibnja do kolovoza. Maksimalna se brzina vjetra statistički značajno smanjuju od sjevernoga dijela Velebitskoga podgorja prema južnomu dijelu.

\section{Literatura - References}

Conrad, V., L. W. Polak, 1950: Methods in Climatology. Harvard University Press, 459 p.

Gaussen, H., 1954: Théorie et classification des climats et microclimats. VIIéme Congrés International de Botanique, 125-130.

Gračanin, M., 1950: Mjesečni kišni faktori i njihovo značenje $u$ pedološkim istraživanjima. Poljoprivredna znanstvena smotra, 12: 51-66.

Gračanin, M., Lj. Ilijanić, 1977: Uvod u ekologiju bilja. Školska knjiga, Zagreb, 289 str.

Hrvatska enciklopedija, 2021: Velebitsko podgorje. Leksikografski zavod Miroslav Krleža, http://www.enciklopedija.hr/Natuknica.aspx?ID=64114. Pristupljeno 15. 4. 2021.

Hrvatska enciklopedija, 2021: Velebitski kanal. Leksikografski zavod Miroslav Krleža, http://www.enciklopedija.hr/Natuknica.aspx?ID=64112. Pristupljeno 15. 4. 2021.

Lang, R., 1915: Versuch einer exakten Klassifikation der Böden in klimatischer und geologischer Hinsicht. Internationale Mitteilungen für Bodenkunde, 5, 313 p.

Martonne, E. de, 1926: Une nouvelle fonction climatique: $\mathrm{l}^{\prime}$ indice d' aridité. La Météorologie, $449 \mathrm{p}$.

Penzar, B., I. Penzar, M. Orlić, 2001: Vrijeme i klima hrvatskog Jadrana. Nakladna kuća »dr. Feletar«, Koprivnica, 258 str.

Seletković, I., I. Tikvić, M. Vučetić, D. Ugarković, 2011: Klimatska obilježja i vegetacija sredozemne Hrvatske. U: 
Šume hrvatskoga Sredozemlja, S. Matić (ur.). Akademija šumarskih znanosti, Zagreb, 142-156.

StatSoft, Inc, 2003: STATISTICA for Windows. Publisher: StatSoft Inc., Tulsa, USA.

Šegota, T., A. Filipčić, 1996: Klimatologija za geografe. Školska knjiga, Zagreb, 471 str.

Šimunić, I., 2013: Uređenje voda. Hrvatska sveučilišna naklada, Zagreb, 260 str.

Ugarković, D., I. Tikvić, M. Šporčić, Ž. Španjol, R. Rosavec, 2017: Utjecaj strukture sastojina na mikroklimu šumskih ekosustava hrasta crnike (Quercus ilex L.) i alepskoga bora (Pinus halepensis Mill.). Nova mehanizacija šumarstva, 38: 57-65.

Ugarković, D., Ž. Španjol, I. Tikvić, D. Kapučija, I. Plišo Vusić, 2019: Microclimate differences in the degradation stages of holm oak (Quercus ilex L.) forests. Šumarski list, 143(9-10): 391-402. https://doi.org/10.31298/sl.143.9-10.1

UNESCO, 1963: Bioclimatical mapo $f$ the Mediterranean zone. Arid Zone Research, 21: 1-60.

Vukelić, J., Đ. Rauš, 1998: Šumarska fitocenologija i šumske zajednice u Hrvatskoj. Sveučilište u Zagrebu, Šumarski fakultet, 310 str.

Vukelić, J., 2012: Šumska vegetacija Hrvatske. Sveučilište u Zagrebu, Šumarski fakultet, Državni zavod za zaštitu prirode, Zagreb, 403 str.

Walter, H., 1955: Die Klimadiagramme als Mittel zur Beurteilung der Klimaverhältnisse für ökologische, vegetationskundliche und landwirtschaftliche Zwecke. Ber. Dtsch. Bot. Ges., LVIII, 8.

\section{Characteristics of Climate in the Area of Velebit Podgorje}

The area of Velebit Podgorje is a climate-specific part of the Adriatic Sea with the strongest wind gusts. The aim of this paper is to analyze some of the main climatic elements and indices in the area of Velebit Podgorje. Climatic data from three meteorological stations were analyzed, namely Senj situated in the northern part of the Velebit Podgorje, and Jablanica, and Karlobag in the south, i.e. in the central part of the area. According to Köppen, the climate in the Velebit Podgorje area is a moderately warm rainy climate. In the area of Senj, summers are almost without a dry period, while for the other two meteorological stations situated south of the area of Velebit Podgorje, summers are hot with extremely dry periods during July and early August. According to the values of the Lang's rain factor, the climate in the area is semi humid. From Senj towards the south of the Velebit Podgorje, the values of the average annual air temperature and the amount of potential evapotranspiration increase, while precipitation amounts and mean wind speed are reduced, however these changes in climatic elements are not statistically significant. Only the maximum wind speed decreases significantly from Senj to Karlobag. Absolute air temperature fluctuation in the area ranged from $-10.4{ }^{\circ} \mathrm{C}$ to $39.7^{\circ} \mathrm{C}$. Maximum wind speed in the area of the Velebit Podgorje was 32.7 Beaufort, and the most frequent wind was east-northeast or northeast.

Keywords: climate, climatic elements, climatic indices, Velebit Podgorje 
Adrese autorâ - Authors' addresses:

Izv. prof. dr. sc. Damir Ugarković* e-pošta: dugarkovic@sumfak.unizg.hr Prof. dr. sc. Ivica Tikvić e-pošta: ivica.tikvic@zg.htnet.hr Izv. prof. dr. sc. Roman Rosavec e-pošta: rrosavec@sumfak.unizg.hr Sveučilište u Zagrebu Fakultet šumarstva i drvne tehnologije Svetošimunska cesta 23 10000 Zagreb HRVATSKA

Martin Nekić, univ. bacc. ing. silv. e-pošta: martin.bozina@gmail.com Otočka 14

53270 Senj HRVATSKA

Krešimir Popić, mag. ing. silv.

e-pošta: kresimir.popic@hrsume.hr Hrvatske šume d.o.o.

Uprava šuma Podružnica Vinkovci Šumarija Lipovac Matije Gupca 5 32246 Lipovac HRVATSKA

Primljeno (Received): 5. 3. 2021.

Prihvaćeno (Accepted): 16. 4. 2021.

${ }^{*}$ Glavni autor - Corresponding author 